\title{
Chemiluminescence 測定による多核好中球機能の検討
}

一一特に担癌患者を中心として——

\author{
平野達雄・中山博司・田㴊純宏 \\ 石井 俊世・下山孝俊・三浦敏 夫 \\ 富田 正雄・辻芳 郎*
}

\begin{abstract}
Tatsuo Hirano, Hiroshi Nakayama, Sumihiro Tabuchi, Toshiyo Ishii, Takatoshi Shimoyama, Toshio Miura, Masao Tomita and Yoshiro Tsuji*
\end{abstract}

The First Department of Surgery, Faculty of Medicine, Nagasaki University

* Department of Pediatrics, Faculty of Medicine, Nagasaki University

\section{【Summary】}

Human polymorphonuclear neutrophils (PMNs) have been shown to have a cytotoxic effect on tumor cells primarily by utilizing the mechanism of oxidative metabolism. The PMN chemiluminesence response (CL) dependent on Luminol (3-aminophthalic hydrazide) was studied in 60 patients with cancers along with 24 patients with benign diseases to determine the oxidative metabolic activities. The mean peak CLR was $45.6+11.6$ relative intensity (RI) ( $m \pm S D)$ in the healthy control group. Although no significant abnormalities were demonstrated either in patients with cancers of the stomach, colon, lung and breast or in subjects with benign disorders such as peptic ulcer, ulcerative colitis, cholelithiasis and so forth, the peak CLR of PMNs obtained from sixteen patients with advanced gastric cancer in which the depth of the tumor invasion is extended to the propria muscle layer or more deeply was $26.7 \pm 12.7$ RI. This was significantly $(p<0.05)$ less than that observed in the healthy control group. The results suggest that PMNs in advanced gastric cancer patients may have defective oxidative metabolistm or impaired tumoricidal and bactericidal activity.

Key words : cancer, polymorphonuclear neutrophil, chemiluminescence, Luminol 


\section{【概 要】}

ヒト多核好中球 (RMN) は腫瘍細胞に対して，おもにその酸化的代謝機構により細胞障害作用をむつことが明らか にされてきた，そこで酸化的代謝活性をみるために，60人の癌患者と 24 人の良性疾患患者にっいて，ルミノール（3aminophthalic hydrazide 添加による PMN の chemiluminescence (CL) を測定した. 対照群のピーク CL 值は 45.6 \pm 11.6 相対強度 (relative intensity, RI) であった. 胃癌, 大腸癌, 肺癌, 乳癌など癌患者や, 消化性潰癔, 潰 瘍性大腸炎, 胆石症などの良性疾患でいすれも対照群との間に有意差は認められなかったが，樑達度が固有筋層以上

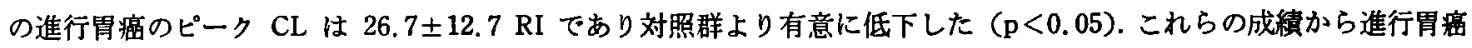
の PMN は酸化的代铸の障害があり,これらの PMN では抗腫瘍作用や抗菌作用が低下していることが示唆された.

\section{I. 緒 言}

細胞障害性 $\mathrm{T}$ 細胞 ${ }^{1,2)}$, 単球・マクロファージ系細 胞 $^{3 \sim 9)}, \mathrm{K}$ 細胞・ NK 細胞 ${ }^{10,11)}$ などは, 生体内に生じた腫 瘍に对して，その成長を阻止（cytostasis），あるいは缠 瘍自体を破壊する (cytolysis).このように cytotoxicity を有する細胞はエフェクター細胞とよばれる。これらに 加え, 多核好中球 (polymorphonuclear neutrophil, PMN) がエフェクター細胞としてにわかに注目を集め てきた. PMN が他のエフェクター細胞に比べて,腫瘍に 対する生体防御機構のなかでどれほどの重みをるった役 割を果たしているのかは不明であるが，腫瘍-宿主間の 状況次第では強い cytotoxicity を示す場も確かに存在 することが明らかにされつつあり ${ }^{121}$ ，単球に相当す る13,14)，あるいは単球を淩ぐ cytotoxicityを示す報 告15)も少なくない.

cytotoxicity の機序はかなり明らかにされている. PMN のその主要な機能である細菌，真菌などの殺菌の 機序が,ここでも重要な働きをしていることがわかって きた. すなわち，酸化的代謝過程のなかで生じた種々の 活性酸素 (スーパーオキサイド $\mathrm{O}_{2}^{-}$，ハイドロキシルラ ジカル. $\mathrm{OH}$, 過酸化水素 $\mathrm{H}_{2} \mathrm{O}_{2}, 1$ 重項酸素 ${ }^{1} \mathrm{O}_{2}$, hypochlorous, acid HOCl など〉が中心となって腫陽細胞 を障害するという(図 1 ).

一方, Allen らによって, PMN が細菌の貪食の際や, 何らかの刺激を受けた際に chemiluminescence (CL, 化 学発光) を生じることが報告された ${ }^{16)}$. 彼らは, ${ }^{1} \mathrm{O}_{2}$ が 産生され，基質に作用して励起状態に戻るとき光を発す ると考えた (図 2)17,18). それ以来, CL に関して多くの 報告があるが，この CL は酸化的代謝過程を反映するも のと考えられている17 211.

このような意味で, 各種癌患者の PMN の CLは, そ の酸化的代謝活性，ひいては cytotoxic activity 評価 する目安にもなる可能性があると考えられる. 悪性腫富

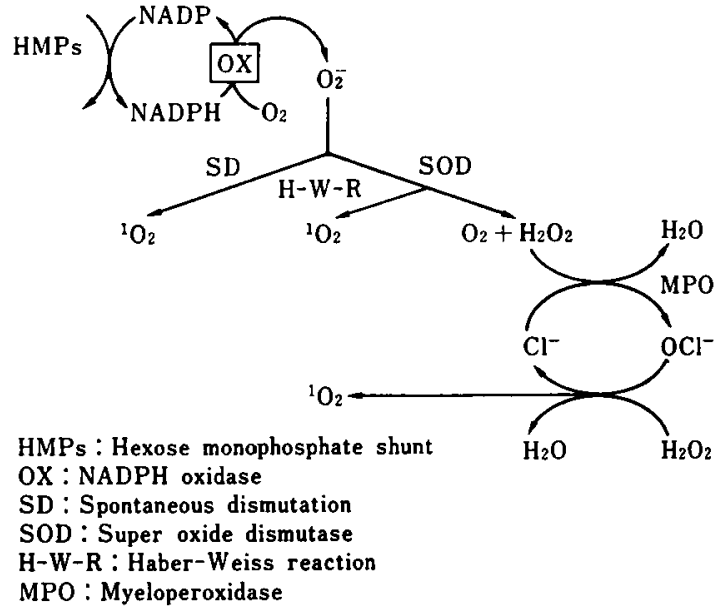

図 1 酸化的代謝

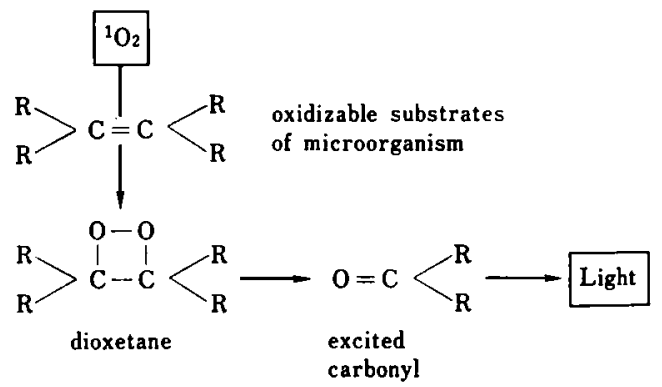

図 2 Chemiluminescence $の$ 機序

に関連した単球の CL の報告はわすかかがらみられる が22,23)，PMN の CL に関しては見当たらず,臨床応用の 多くは感染との関係で論じられてきた 20,24-26). 著者らは 癌患者を中心に PMLの CL を測定したので，良性疾患 の CL の結果も合わせてここに報告し検討を加えたい.

\section{II. 材料と方法}

\section{1) 対象症例}

1982 年に長崎大学第 1 外科で治療した患者のうち, 胃 


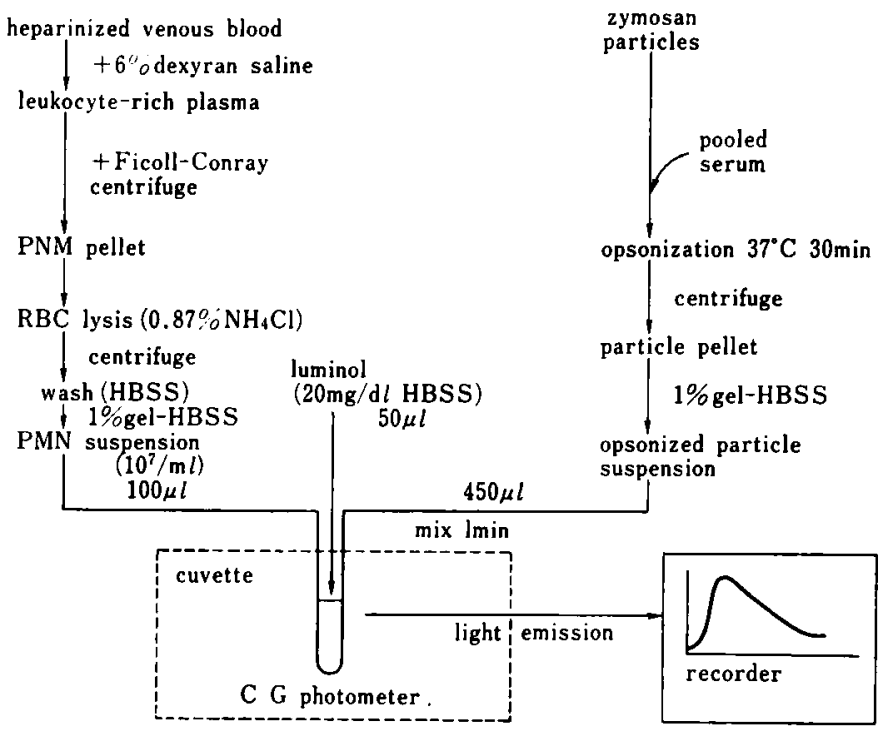

图 3 The procedure of luminol-dependent chemiluminescence assay

癌 25 例, 食道癌 3 例, 大腸癌 10 例，乳癌 6 例，肺癌 11 例，消化性潰瘍 4 例，潰場性大腸炎 7 例，肝硬变 5 例 (肝癌合併 2 例), 胆石症 7 例 (無黄疸), 閉塞性 黄 疸 4 例 (胆石 1 例，悪性腫瘍 3 例)，重症感染症 2 例につい て PMN の CL を測定した，健康成人 8 例を対照群とし た.

\section{2） PMN の分類}

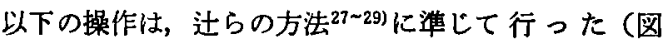
3). 少量のヘパリン (Novo 社) を含を disposable 注射 器 (テルモシリンジ) で $20 \mathrm{~m} l$ の静脈血を採り, $6 \%$ デ キストラン生食 (dextran T 110 P.F.C.) を 4 5 ml に 加えて軽く摬汼したのち，注射器を逆立て室温で約 30 分置いた. 上層の leukocyte-rich plasma を約 $3 \mathrm{ml}$, Ficoll-Conray (9\% Ficoll, 33.4\% Conray) の上に静か に上層させ, 1, $700 \mathrm{rpm}, 30$ 分遠沈した (HITACHI CENTRIFUGE O3P). 上清みを除き，多核白血球と赤血球を 含むペレットに $0.87 \% \mathrm{NH}_{4} \mathrm{Cl}$ 約 $10 \mathrm{ml}$ 加えて約 15 分 間ローテーターで静かに回転翼拌して溶血させた. 1,100 $\mathrm{rpm}, 5$ 分間遠沈して上清みを除き，このペレットに $1 \%$ gel-Hanks 液 (Hank's balanced salt solution without phenol red, GIBCO) を加えて 2 回洗浄し, 細胞数 $10^{7} /$ $\mathrm{m} l$ の PMN 浮遊液を作成した.

3）ルミノール溶液の作成

ルミノール (Luminol, 3-aminophthalic hydrazide, SIGMA）を Hanks 液にて溶解して湌度 $0.2 \mathrm{mg} / \mathrm{ml}(\mathrm{pH}$ 7.4) とし,ミリポアフィルター $(0.5 \mu)$ で濾過して $4^{\circ} \mathrm{C}$ で保存した。

\section{4) CL 測定器の調整}

photometer (Amico CHEM-GLOW) を用い, まず multiplier switch (感度調整) を 10 に, dumping switch を on に blanket adjust switchを low にセットした. 測定値は photometer に接続したレコーダー（島津製作 所）に経時的に記録させ, ペン速度 $10 \mathrm{~mm} / \mathrm{min}$, input voltage $50 \mathrm{mV}$ で 10 分間测定した.

5) CL の測定

付属の直径 $6 \mathrm{~mm}$ の cuvette にルミノール溶液 $50 \mu l$ を入れ，ついで $1 \%$ gel-Hanks 液 $400 \mu l$, ザイモザン浮 遊液 $50 \mu l$ を入れた. 最後に PML の浮遊液 $100 \mu l$ (106 個)を入れ，同時にレコーダーを始動させた. cuvette 1 分間よく靦拌したのち photometer の holder に挿入し head を测定位置に回す.記録紙の綎軸は CL の相対強度 (relative intensity, RI) を示し, multiplier switch 10 では range は 0〜100RI で表される. 横軸は測定時間を示す.

6) 統計処理

CL の比較には CL 曲線のピーク值を用い, Student の $\mathrm{t}$ 検定を行った.

\section{III. 成 綪}

対照群の CL 曲線は急速な立ち上がりを示し，30 秒 から 1 分内にピークがあり，その後次第に減衰した．ピ

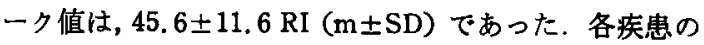
ピーク值の比較を図 4 に示した。

i）胃 癌：ピーク CL 值は $34.2 \pm 16.1 \mathrm{RI}$ であり 


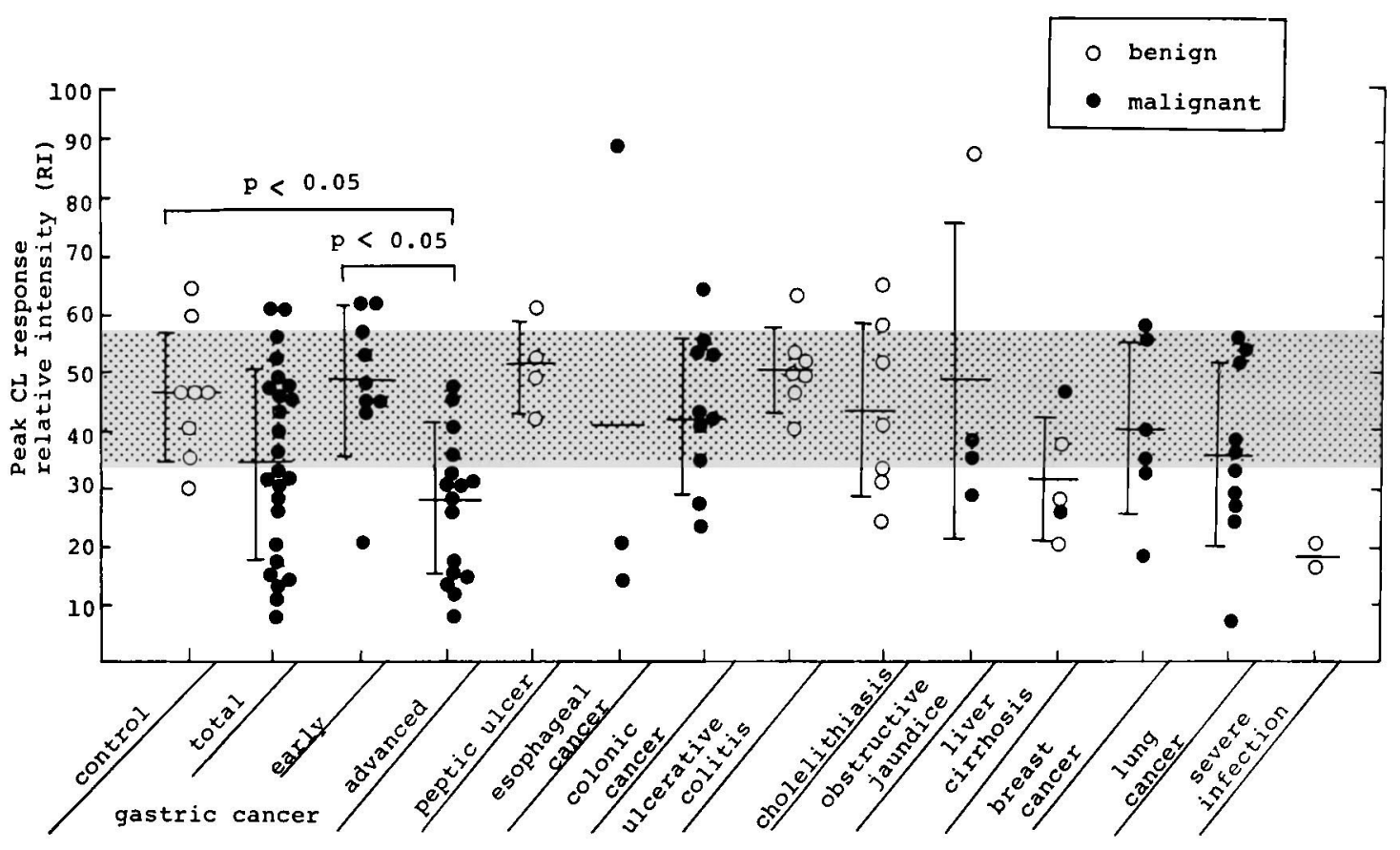

図 4 各種疾患のピーク CL 值

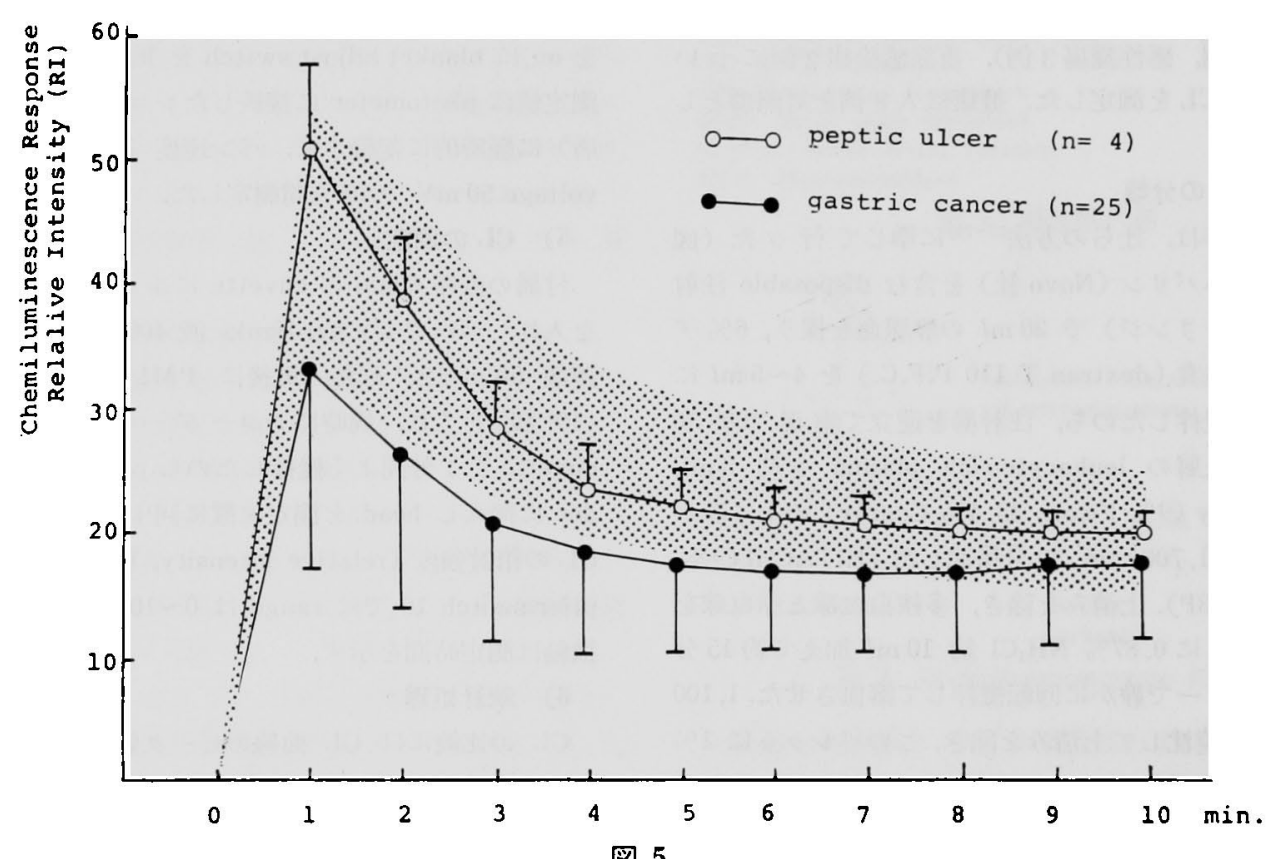

図 5

対照の 76\% に低下したが有意差はなかった．CL 曲線 （図 5 ）は立ち上がりが緩徐で低い CL を示した。 これ を早期癌 $(n=9)$ と進行癌 $(n=16)$ とに分けてみると, 早期癌のピーク CL 值は, 47.7 $12.4 \mathrm{RI}$ で対照群との

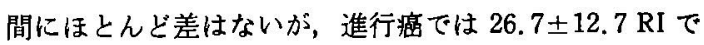

あり，対照群の $58.6 \%$ に低下し有意差が認められた $(p<0.05) . C L$ 曲線は明らかに対照群よりも低下した (図6).

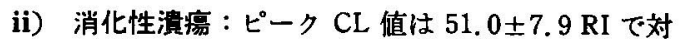
照よりわずかに高いが有意差はなかった，CL 曲線は初 
平野 - Chemiluminescence 測定による多核好中球機能の検封
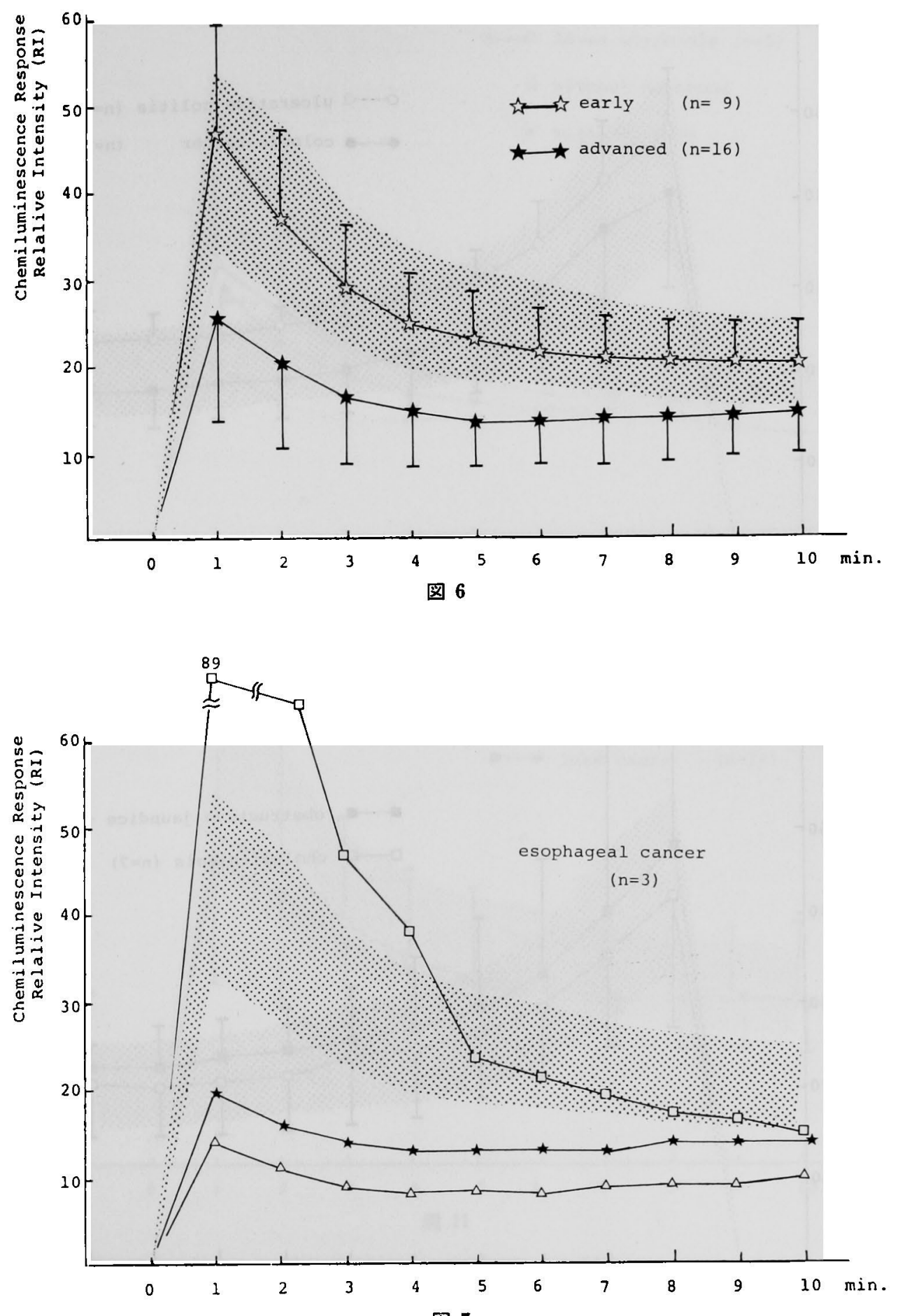

図 7

期の 2 分では対照より少し高いが, その後はほとんど差 を譂めなかった.

iii）食道癌：3例と少ないが，いずれも進行癌であ
り, 3 例のピーク值はそれぞれ 14, 20,89 RI であった. 高值を示した 1 例のみ治療切除を行い得たが, 低下の 2 例は非治應切除に終わった (図7). 

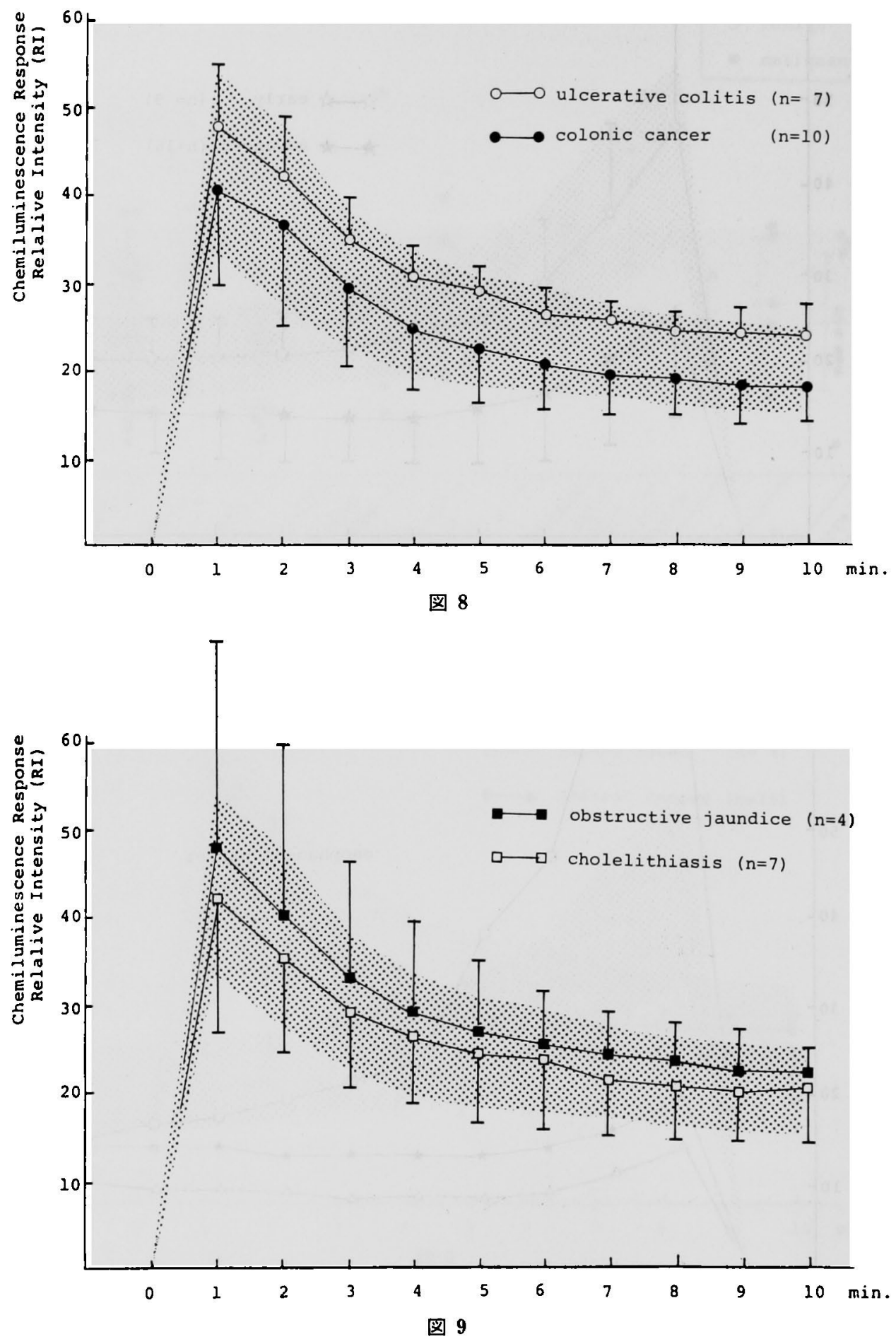

iv）大腸癌：ピーク值は $42.7 \pm 13.4 \mathrm{RI}$ であり，CL 曲線も対照とほとんど差はなかった（図 8 ).

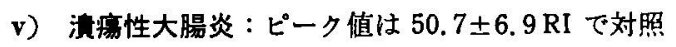

より $11 \%$ 高いが有意差はなかった。この7例中 2 例は 術後の症例であり，それぞれ 52,40RI と正常であった。 活動型で入院中の 2 例中 1 例は全結腸型でピーク值は 

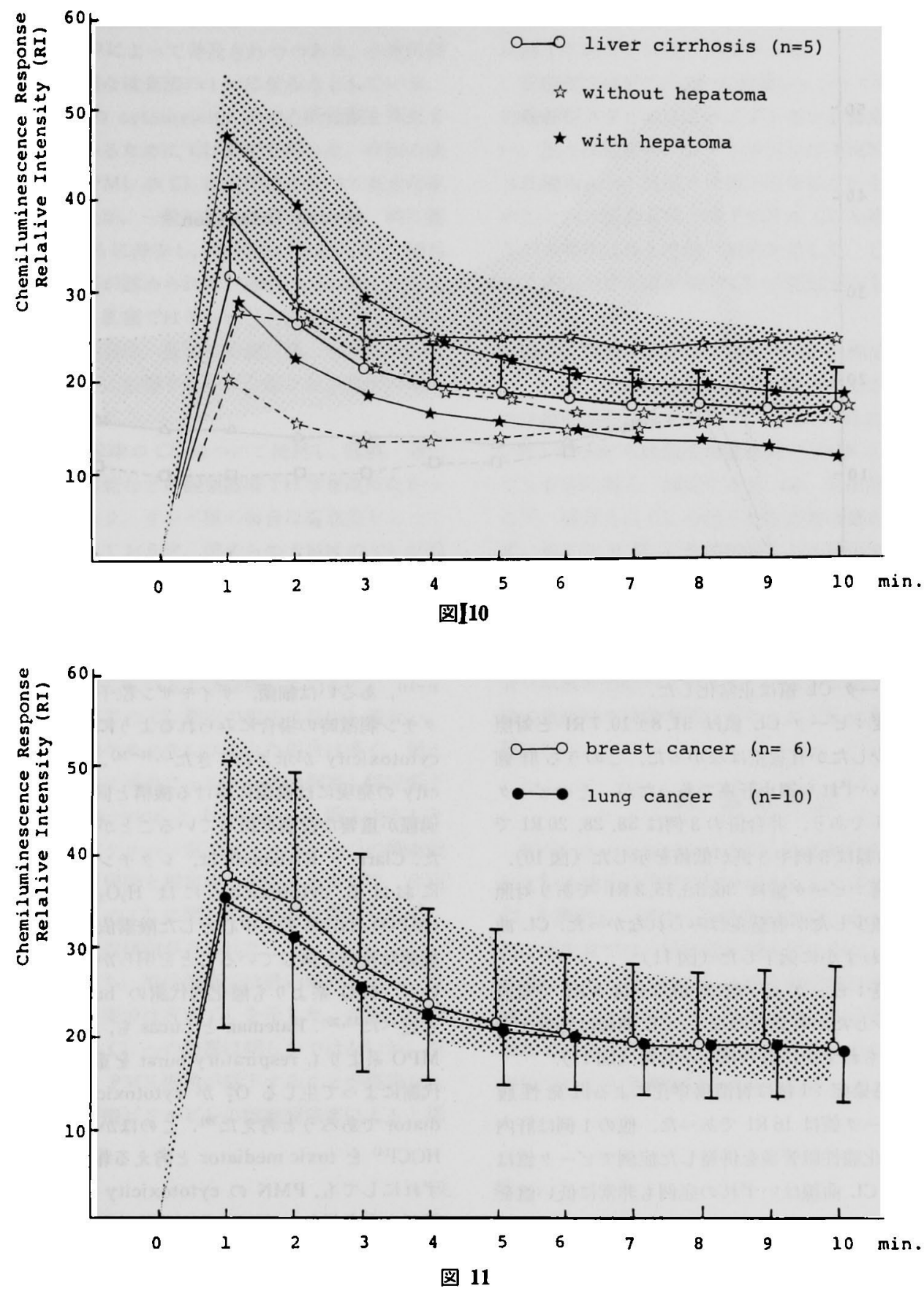

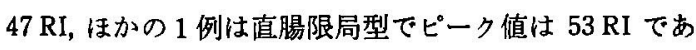
った. 残る 3 例は外来患者でピーク值はそれぞれ 50, 50， $63 \mathrm{RI}$ であった．少数例の検討であるが，活動性，罪患 筑囲などによる CL の差はみられなかった（図 8).

vi）胆石例：黄痽や急性炎症状のない胆石症では

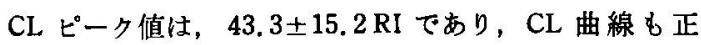

常であった（㘠 9).

vii）閉塞性黄㾝：ピーク值は, 48.8土27.1 RI で対照 群と変わらなかったが，このうち3 例は悪性腫癔で，そ れぞれのピーク值は $30,37,40 \mathrm{RI}$ とやや低い傾向を示 した．他の 1 例は総胆管結石による閉塞性黄疮でピーっ 值は 89 RI と高い值を示したが（図 9), 術後は黄疸の消 


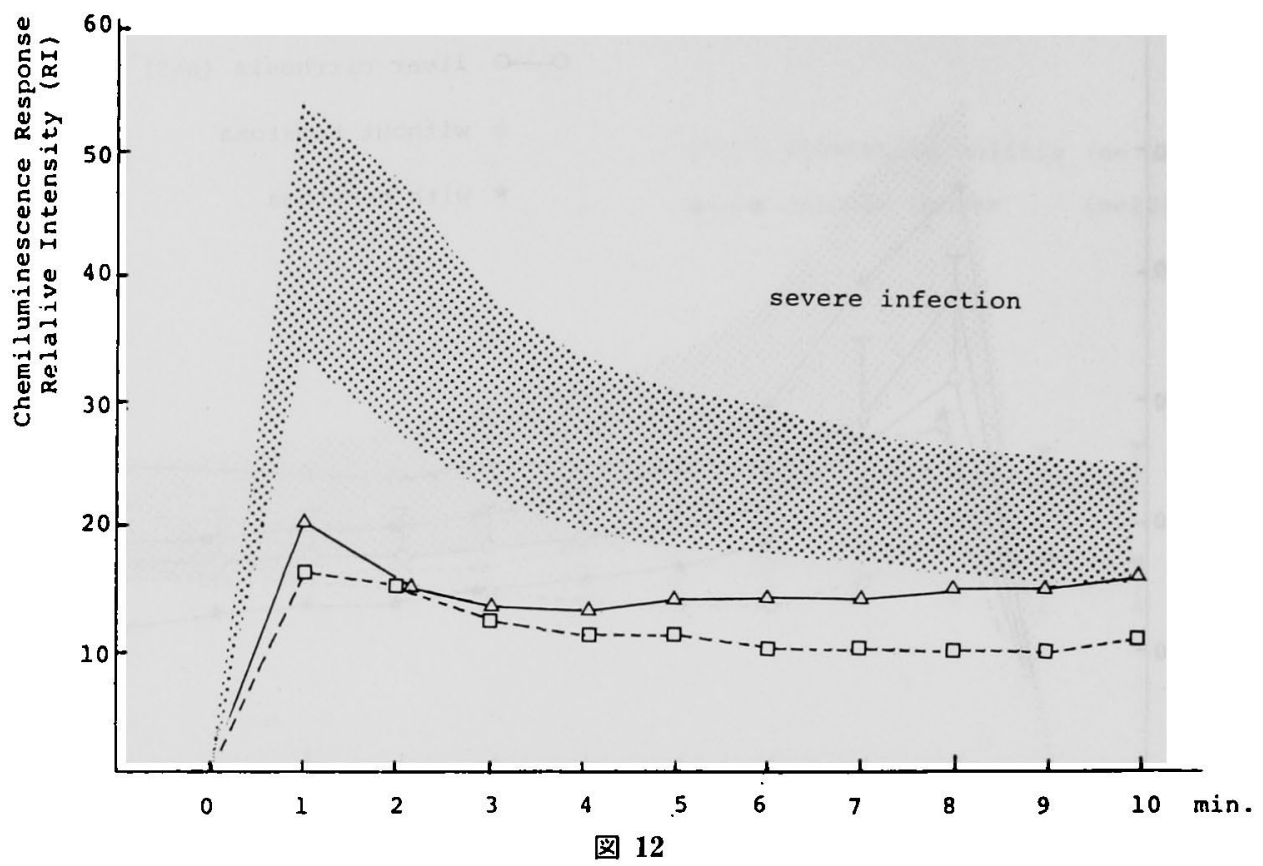

失とともにピーク CL 值は正常化した.

viii）肝硬変：ピーク CL 值は $31.8 \pm 10.7$ RI と対照 の70\%に減少したが有意差はなかった.このうち肝癌 合併の 2 例はいずれも細小肝癌であったが，そのピーク 值は 47,26 RI であり，非合併の 3 例は $38,28,20 \mathrm{RI}$ て あった. CL 曲楾は 5 例中 3 例が低值を示した（図 10）。

ix）肺 癌：ピーク值は 36.3 15.3 RI であり対照 群の $80 \%$ に減少したが有意差はみられなかった. CL 曲 線む正常よりわずかに低下した（図 11）.

x）乳 癌：ピーク CL 值は 40.2土14.8RI で対照 の $88 \%$ に減少したが有意差はなく,CL 曲線は肺癌と同 様に対照よりもわずかに近い値を示した（図 11）.

xi）重症感染症：1 例传潰瘍穿孔による沉 発 性 腹 膜炎でありピーク値は 16 RI であった，他の 1 例は肝内 結石症に急性化朖性胆管炎を併発した症例でピーク值は 20 RI であり，CL 曲線はいずれの症例も非常に低い值を 示した（図 12）.

\section{IV. 考案}

PMN の腫瘍に対するエフェクター細胞としての働き が注目されつつある.しかし cytotoxicity の誘導の機 序に関してはなお不明の点が多い.PMN がなんら刺激 なしに spontaneous cytolysis を示すという例外的な報 告もみられるが30)，実験上は抗体依存性細胞免疫 antibody dependent cell-mediated cytotoxicity (ADCC) ${ }^{13}$,
31 34)，あるいは細菌，ザイモザン粒子などの貪食時やレ クチン刺激時の場合にみられるように non-specific な cytotoxicity が示されてきた ${ }^{15,35 \sim 38)}$. そして cytotoxicity の発現には殺菌における機楆々同様に酸化的代 謝 過程が重要な役割を担っていることが明らかにされてき た. Clark と Klebanoff は, レクチン刺激や異物貪食時 における cytotoxicity には $\mathrm{H}_{2} \mathrm{O}_{2}$. Myeloperoxidase (MPO)-Halide 系を中心とした酸素依存性の殺菌機構が 重要な役割を演じていることを明らかにし，ADCCにお いて MPO 系よりも酸化的代謝の burst が重要である と述へた ${ }^{33,35)}$. Hafeman と Lucas も, ADCCにおいては MPO 系より\& respiratory burst を重視し，この酸化的 代謝によって生じる $\mathrm{O}_{2}^{-} か ゙$ cytotoxicity の主要な mediator であろうと考えた ${ }^{39)}$ 。このほか $\mathrm{H}_{2} \mathrm{O}_{2}{ }^{40)}, \cdot \mathrm{OH}^{41)}$ ， $\mathrm{HOCl}^{14)}$ toxic mediator と考える報告がみられる。い ずれにしてb，PMN の cytotoxicity には酸化的代謝機 構が主役を果たしているとする考え万が中心となってい る. Allen らによる CL 測定 ${ }^{16)}$ は，この酸化的代謝活性 を総合的に反映する検查法であるといわれている。しか し，覀性腫瘍との関連で述ぺられた報告は，単球の CL についてわずかにみられるが, PML の CL に関しては 見当たらない，この理由は，PMN のエフェクター細胞 としての役割がそれほど注目されていなかったことと， CL 測定の歴史が浅く，まだ十分に普及していないため だと思われる. CL の測定は殺菌機構の解明や感染 疾患 
における PMN 機能測定に応用されており，本邦では过 らのグループ27 299によって普及されつつあり，小巟科領 域においては重要な検查法の1つになるうとしている.

著者らは PMN の cytotoxicity の中心的役割を果たす 酸化代謝活性をみるために CL 測定を行った. 今回の成 綘では，癌患者 PML のCL は対照群に比べて有意な差 は得られなかったが，一般に低い傾向を示した，特に胃 癌では対照の $76 \%$ に減少し，進行癌だけをみると $59 \%$ に減少して有意差が認められた. 肺癌 む約 $80 \%$ に低下 したが，大腸癌，乳癌ではそれほどの変化はみられなか った．腫癔の発生部位，患者の栄趇状態，その他の因子 が CLにどのように影響するかは今後なお多数例の検討 を要すると思われる.

Kitahara らは単球の CL について検討し, 乳癌, 消化 器癌, 泌尿生殖器癌などの固型腫瘍では有意差はなかっ たが高い僋向がありリンパ腫の場合は有意差をもって

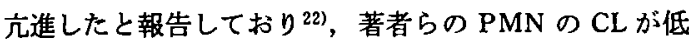
い㑯向を示した成績とは逆であった. Robinsonらは paraprotein が単球の CL をほとんど低下させるのに対 し, PMN の CL に変化を及ぼさないことから,両者のレ セプターが異なることによると推測している23.

潰啲性大腸炎患者の CL 测定の報告は見出し得ない。 本疾患の PMN のケモタキシスをみた報告は多く，例え ば Rhodes らはミリポアフィルター法で測定し軽度低下 を認め ${ }^{42)}$, Hermanowicz と Nawarska む低下すること を述へている43)。クローン病でマクロファージの機能低 下を認め，これを病因と推定する報告むあるが44)，今回 の検討では PMN のCLに関しては異常は認められず, むしろ対照より六進傾向がみられた。

閉塞性黄疸のうち，悪性腫瘍では低い傾向を示し，良 性疾患である胆石症では高いCL を示した，今回の成績 ではビリルビンの CL への影響は明らかではないが，新 生児重症黄㾝では PMN 機能が低下することが報告され ており、これは間接ビリルビンの細胞膜障害によると推
測されている ${ }^{45)}$. 閉塞性黄疸時の直接ビリルビンの影響 に関する論文には接し得なかった。

肝硬変では肝内門脈一大循環シャントの増加, 網 内采 の機能低下などによりェンドトキシン血症に陥りやす い，辻らは微量のエンドトキシンは PMNのケモタキシ スを增加させ，大量では低下させることを示した ${ }^{46)}$ 。こ のことから肝硬変症では PMN の CLの増加が予想され たが実際にはむしろ低下傾向を示した．しかし，肝硬変 症に感染を伴えば早期に CL が変化するものと思われ る.

感染症疾患に関する PMN の CL の測定の報告は少な い. PMN の酸化的代謝過程に障害のある慢性肉芽腫症 では重症感染をきたしやすく, $\mathrm{CL}$ の発生はみられな (24). Barbar らは急性細菌感染で PMN の CL は対照よ りも有意に高く，回復すると $C L$ も正常化したと述べ た ${ }^{25)}$ 。禓井らは CLの明らかな高值は認められておら す，新生児 $\mathrm{B}$ 群 $\beta$-連鎖球菌による㗙膜炎患者の急性期 では CL は低下したと述べている ${ }^{47)}$. Graft らは cystic fibrosis 患者はしばしば肺感染症を反復するために PMN のCL を测定したが有意差は認めていない26)。著 者らは重症感染の 2 例に CL の著明な低下を認めた。感 染の重症度や持続期閒などにより CL は変化するものと 思われた。

\section{V.おわりに}

PMN の cytotoxicity の中心的役割を果たすと考えら れている酸化的代謝活性を知るために癌患者を中心に CL を測定し，併せて良性疾患の CL についても報告し た。癌患者では一般に低下傾向がみられ，進行胃癌では 有意に低下した. PMN の酸化的代謝の低下が癌発育の 原因の 1 つであるのか, 癌発育による結果であるのか, また CL 測定が真に cytotoxicty の目安になり得るか否 かについても今後検討の余地がある.

献

3) Hibbs, J.B., Lambert, L. and Remington, J. : Possible role of the macrophage-mediated nonspecific cytotoxicity in tumor resistance. Nature [New Biol], $235: 48,1972$.

4) Alexander, P. and Evans, R. : Endotoxin and double-stranded RNA render macrophages cytotoxic. Nature, $232: 76,1971$.

5) Keller, R.: Mechanisms by which activated nor- 
mal macrophages destroy sygeneic rat tumor cells in vitro. Immunology, $27: 285,1974$.

6) Kaplan, A.M., Morahan, P.S. and Regelson, W. : Induction of macrophage-mediated tumor cell cytotoxicity by pyran copolymer. J. Natl. Cancer Inst., $52: 1919,1974$.

7) Mantovani, A., Tagliabue, A., Dean, J.H., Jerrels, T. and Herberman, R. : Cytolytic activity of circulating human monocytes on transformed and untransformed fibroblasts. Int. J. Cancer, $23: 28,1979$.

8) Cameron, D.J. and Churchill, W.H. : Cytotoxicity of human macrophages for tumor cells. Enhancement by human lymphocyte mediators. J. Clin. Invest, $63: 977,1979$.

9) Jarrels, T.R., Dean, J.H., Richardson, G.L., Cannon, G.B. and Herberman, R.B. : Increased monocyte-mediated cytostais of lymphoid cell lines in breast and lung cancer patients. Int. J. Cancer, $23: 768,1979$.

10) Heberman, R.B. and Holden, H.T. : Natural cell-mediated immunity. Adv. Cancer Res., 27 : 305, 1978.

11) Ojo, E. and Wigzell, H. : Natural killer cells may be the only cells in normal mouse lymphoid cell populations endowed with cytolytic ability for antibody-coated tumor target cells. Scand. J. Immunol., $7: 297,1878$.

12）仙道富士郎・井上富夫：癌に対する自然抵抗性の one small compartmentとしての多核白血球. Oncologia, $1: 10,1982$.

13) Korec, S., Herberman, R.B., Dean, J.H. and Cannon, G.B. : Cytostas is of tumor cell lines by human granulocytes. Cellular Immunol., 53 : $104,1980$.

14) Weiss, S.J. and Slivka, A. : Monocyte and granulocytemediated tumor cell destruction. A role for the hydrogen-peroxide-myeloperoxidase-chloride system. J. Clin. Invest, $69: 255$, 1982.

15) Clark, R.A. and Klebanoff, S.J. : Role of the Myeloperoxidase $-\mathrm{H}_{2} \mathrm{O}_{2}$-halide system in Concanavalin A-induced tumor cell killing by human neutrophils. J. Immunol., $122: 2605,1979$.

16) Allen, R.C., St jernholm, R.L. and Steele, R.H. :
Evidence for the generation of an electronic excitation state ( $s$ ) in human polymorphonuclear leukocytes and its participation in bactericidal activity. Biochem Biochem Biophys Res Commun, $47: 679,1972$.

17) Allen, R.C. : Halide dependence of the myeloperoxidase-mediated antimicrobial system of the polymorphonuclear leukocyte in the phenomenon of electronic excitation. Biochem Biophys Res Commun, $63: 675,1975$.

18) Allen, R.C.: Therole of $\mathrm{pH}$ in the chemiluminescent response of the myeloperoxidasehalide-HOOH antimicrobial system. Biochem Biophys Res Commun, 63 : 684, 1975.

19) Cheson, B.D., Christensen, R.L., Sperling, R., Kohler, B.E. and Babior, B.M. : The origin of the chemiluminescence of phagocytosing granulocytes. J. Clin. Invest, 58 : 789, 1976.

20) Stevens, P., Winston, D.J. and Van Dyke, K. : In vitro evaluation of opsonic and cellular granulocyte function by luminol-dependent chemiluminescence : utility in patients with severe neutropenia and cellulardeficiency states. Infect Immunity, $22: 41,1978$.

21) Rosen, H. and Klebanoff, S.J. : Chemiluminesence and superoxide production by myeloperoxidase deficient leukocytes. J. Clin. Invest, $58: 50,1976$.

22) Kitahara, M., Eyre, H.J. and Hill, H.R. : Monocyte function and metabolic activity in malignant and inflammatory disease. J. Lab. Clin. Med., $93:$ 472, 1979.

23) Robinson, J.P. and Penny, R. : Chemiluminescence response in normal human phagocytes. II. Effect of paragroteins. J. Clin. Lab. Im. munol., $7: 219,1982$.

24) Allen, R.C., Stjernholm, R.L., Reed, M.A., Harper, T.B., Gupta, S., Steele, R.H. and Waring, W.W. : Correlation of metabolic and chemiluminescence responses of granulocytes from three female siblings with chronic granu. lomatous disease. J. Infect Dis., $136: 510,1977$.

25) Barbour, A.G., Allred, C.D., Solberg, C.O. and Hill, H.R. : chemiluminescence by polymorphonuclear leukocytes from patients with ac- 
tive bacterial infection. J. Infect Dis., $141: 14$, 1980.

26) Graft, D.F., Mischler, E., Farrel, P.M. and Busse, W.W. : Granulocyte chemiluminescence in adolescent patients with cystic fibrosis. Am. Rev. Resp. Dis., 125 : 540, 1982.

27）辻 芳郎·楊井正紀・神戸正彦・遠矢芳一：多核 好中球の chemiluminescence 測定法の検討。医 学のあゆみ, $102: 161,1977$.

28）楊井正紀・森 剛-一・福田友子・辻 芳郎：ヒト 多核白血球のルミノール添加による chemiluminescence 測定の検討. 医学のあゆみ, $112: 594$, 1980.

29）森 刪一・楊井正紀・福田友子・辻 芳郎：ルミ ノールを用いたヒト多核好中球の chemiluminescence 測定の基礎的検討. 厚生省特定疾患「免疫 不全症候群」調查研究班昭和 54 年度研究調 查 報 告書, 1979. pp. 251 260.

30) Chee, D.O., Townsend, Jr, C.M., Galbraith, M.A., Eibber, F.R. and Morton, D.L. : Selective reduction of human tumor cell populations by human granulocytes in vitro. Cancer Res., $38: 4534,1978$.

31) Gale, R.P., Zighelboim, J., Ossorio, C. and Fahey, J.L. : Immunologically specific tomor cell destruction by human polymorphonuclear leukocytes. Clin. Res., $22: 418$ A, 1974.

32) Gale, R.P. and Zighelboim, J. : Polymorphonuclear leukocytes in antibody-dependent cellular cytotoxicity. J. Immunol., $114: 1047,1975$.

33) Clark, R.A. and Klebanoff, S.J. : Studies on the mechanism of antibody-dependent polyorphonuclear leukocyte-mediated cytotoxicity. J. Immunol., $119: 1413,1977$.

34) Drorak, A.M., Connel, A.B., Proppe, K. and Dvorak, H.F. : Immunologic rejection of mammary adnocarcinoma (TA $3-\mathrm{St}$ ) in $\mathrm{C} 57 \mathrm{BL} / 6$ mice : Participation of neutrophils and activated macrophages with fibrin formation. J. Immunol., $120: 1240,1978$.

35) Clark, R.A. and Klebanoff, S.J. : Neutrophilmediated tumor cell cytotoxicity : Role of the peroxidase system. J. Exp. Med., 141 : 1442,
1975.

36) Simchowitz, L. and Schur, P.H. : Lectin-dependent neutrophil-mediated cytotoxicity. I. Characteristics. Immunology, $31: 303,1976$.

37) Takasugi, M., Akira, D. and Kinoshita, K. : Granulocytes as effectors in cell-mediated cytotoxicity of adherent target cells. Cancer Res., $35: 2169,1975$.

38) Nakayama, M., Sendo, F., Miyake, T., Fuyama S., Arai, S. and Kobayashi, H. : Nonspecific inhibition of tumor growth by allosensitized lymphocytes. I. Participation of polymorphonuclear leukocytes. J. Immunol., $120: 619,1978$.

39) Hafeman, D.G. and Lucas, Z.J. : Polymorphonuclear leukocyte-mediated, antibody-dependent, cytotoxicity against tumor cells : dependence of oxygen and the respiratory burst. J. Immunol., $123: 55,1979$.

40) Weiss, S.J., Young, J., LoBuglio, A.F. and Slivka, A. : Role of hydrogen peroxide in nutrophil-mediated destruction of cultured endothelial cells. J. Clin. Invest, $68: 714,1981$.

41) Borregaard, N. and Kragballe, K. : Role of oxygen in antibody-dependent cytotoxicity mediated by monocytes and neutrophils. J. Clin. Invest, $66: 676,1980$.

42) Rhodes, J.M. and Jewell, D.P. : White cell chemotaxis in Crohn's disease and ulcerative colit is. Gut, $20: 436,1979$.

43) Hermanowicz, A. and Nawarska, Z. : Chemota$x$ is and random migration of polymorphonuc lear leukocytes in ulcerative colit is examined by the agarose method. Scand. J. Gastroent, $16: 961,1981$.

44) Ward, M. : The pathogenesis of Crohn's disease Lancet, $2: 903,1977$.

45）野田弘之：ヒト顆粒球機能に関する研究一特に感 染症との関係一，炎症，1:65, 1980.

46）辻 芳郎・松田静宗-野田弘之：好中球走化性異 常の臨床. 臨休血液, $19: 904,1978$.

47）楊井正紀・辻 芳郎：Chemiluminescence によ る顆粒球機能検查の臨床的意義. 小児科, 22 : 471, 1981 . 